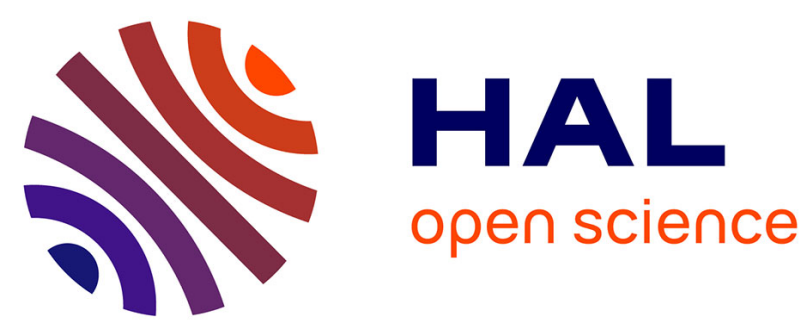

\title{
Community Structure of Tintinnid Ciliates of the Microzooplankton in the South East Pacific Ocean: Comparison of a High Primary Productivity with a Typical Oligotrophic Site
}

John R. Dolan, Audrey Gimenez, Veronique Cornet, Alain de Verneil

\section{To cite this version:}

John R. Dolan, Audrey Gimenez, Veronique Cornet, Alain de Verneil. Community Structure of Tintinnid Ciliates of the Microzooplankton in the South East Pacific Ocean: Comparison of a High Primary Productivity with a Typical Oligotrophic Site. Journal of Eukaryotic Microbiology, 2016, 63 (6), pp.813-822 10.1111/jeu.12328 . hal-01325389

\section{HAL Id: hal-01325389 \\ https://hal.sorbonne-universite.fr/hal-01325389}

Submitted on 6 Jun 2016

HAL is a multi-disciplinary open access archive for the deposit and dissemination of scientific research documents, whether they are published or not. The documents may come from teaching and research institutions in France or abroad, or from public or private research centers.
L'archive ouverte pluridisciplinaire HAL, est destinée au dépôt et à la diffusion de documents scientifiques de niveau recherche, publiés ou non, émanant des établissements d'enseignement et de recherche français ou étrangers, des laboratoires publics ou privés. 

East Pacific Ocean: comparison of a high primary productivity with a typical oligotrophic site

John R. Dolana, Audrey Gimenez ${ }^{\mathrm{b}}$, Veronique Cornet-Barthaux ${ }^{\mathrm{b}}$, and Alain de Verneil ${ }^{\mathrm{b}}$

a Sorbonne Universités, UPMC Univ Paris 06, CNRS UMR 7093, Laboratoire

d'Océanographie de Villefranche de Villefranche-sur-Mer (LOV), 06230 Villefranche-sur-

Mer, France

Telephone number +33493763822

$12 \quad$ FAX number +33 4763834

e-mail:dolan@obs-vlfr.fr

bMIO (Institut méditerranéen d'océanologie), Campus de Luminy, 13288 Marseille Cedex 9, France.

\section{Correspondence}

John R. Dolan, CNRS, UMR 7093, B.P. 28, Station Zoologique, Laboratoire

d'Océanographie de Villefranche-sur-Mer, 06230 Villefranche-sur-Mer, France;

dolan@obs-vlfr.fr

\section{ABSTRACT}

24 Transient 'hot spots' of phytoplankton productivity occur in the generally oligotrophic Southern Pacific Ocean and we hypothesized that the population structure of tintinnid ciliates, planktonic grazers, would differ from that of a typical oligotrophic sites. Samples were collected over a 1 week period at each of two sites between Fiji and Tahiti: one of elevated chlorophyll $a$ concentrations and primary productivity with an abundance of Nfixing cyanobacteria Trichodesmium, and a distant oligotrophic site. Tintinnid abundance differed between the sites by a factor of 2 . A single species (Favella sp.), absent from the oligotrophic site, highly dominated the 'hot spot' site. However, total species richness was identical (71 spp) as well as short-term temporal variability (2-4

33 days). At both sites species abundance distributions most closely fit a log-series or lognormal distribution and the abundance distributions of ecological types, forms of distinct lorica oral diameter, were the typical geometric. Morphological diversity was only slightly lower at the high productivity site. We found that communities of these plankton grazers in 'hot spots' of phytoplankton productivity in oligotrophic systems differ little from surrounding oligotrophic areas.

Keywords: biogeography, biodiversity, plankton, species abundance distribution, Choreotrichia, Trichodesmium

TINTINNIDS are loricate ciliates of the marine microzooplankton which groups heterotrophic or mixotrophic planktonic organisms ranging in size from 20 to $200 \mu \mathrm{m}$. Microzooplankton are thought to account for the consumption of most of the primary production in the world ocean (Calbet \& Landry 2004). While microzooplankton is 
usually numerically dominated by ciliates and heterotrophic dinoflagellates, it is actually

51 a very heterogenous group taxonomically, ecologically, and morphologically (e.g., Beers 1982). It commonly includes many other protist taxa such as acantharia and radiolaria as well as the larval forms of metazoan taxa. Within this heterogeneous group, tintinnid

54 ciliates are a species-rich group, coherent in terms of phylogeny, ecology and morphology, and are also relatively well studied (Dolan 2013).

Tintinnids are characterized by the possession of a shell or lorica into which the ciliate cell contracts when disturbed. Morphology and structure of the lorica is classically the basis for distinguishing species and grouping higher-level taxa, although its utility has been regularly disputed (e.g., Agatha et al. 2013; Santoferrara et al. 2016). The aperture through which the ciliate cell extends when swimming and feeding, termed the lorica oral opening, is a taxonomically conservative characteristic of the lorica (Laval-Peuto \& Brownlee 1986). It is also a key ecological character because the size of the opening, the lorica oral diameter (LOD), is related not only to the maximum prey size ingested, but also the optimum prey size in terms of maximum clearance rate, and the maximum rate of cell division (Dolan 2010; Montagnes 2013). Tintinnid species of

66 similar LOD are then ecologically similar in terms of feeding characteristics and maximum growth capacity. Not surprisingly perhaps, assemblages of tintinnids appear to be organized by mouth size (Dolan et al. 2009; 2013).

69 The structure of tintinnid populations has been studied in a wide variety of marine systems. In species-rich assemblages (tropical, subtropical and temperate systems), species abundance distributions resemble a long-tailed lognormal or log72 series distribution, as is the case for most species-rich communities (e.g. Magurran 1974). Grouping organisms by the size of the LOD, rather than species identity, reveals a geometric distribution. The most densely populated LOD size-classes contain not only the dominant tintinnid species but generally several other species as well, species of apparently similar ecological characteristics, ecological redundant or stand-in species, accompanying the dominants. This pattern has been found in tropical and subtropical assemblages (Dolan et al. 2007; Dolan et al. 2013; Sitran et al. 2007). In contrast, the relatively species-poor assemblages of high latitudes (i.e., polar and sub-polar) do not show the same pattern. Species richness, as well as species redundancy, is markedly

81 lower and dominant species are alone in their size classes. This pattern was been reported for assemblages in both the Southern (Santoferrara \& Alder 2012) and the Northern Hemisphere (Dolan et al. 2016). While the patterns appear coherent among

84 similar systems, little is known with regard to temporal variability over short timescales or responses to transient changes in the environment. To our knowledge only the sub-tropical N.W. Mediterranean tintinnid assemblages have been studied in this regard.

87 The assemblages were found to be fairly stable over a period of 4 weeks. There was an invariant set of dominant core species accompanied by their redundants, and a variable assemblage of transient species (Dolan et al. 2009). However, the study site was also quite stable in terms of the hydrology and most biological parameters (Anderson et al. 2009). Variability is perhaps of most interest in tropical assemblages with the twin puzzling characteristics of high species richness and low abundances (Kofoid 1930).

Once thought to be stable 'desert areas' of the world ocean, tropical oligotrophic gyres are now known to be subject to transient phytoplankton blooms, many associated with blooms of the N-fixing cyanobacteria Trichodesmium (Westbury \& Siegel 2006; Wilson \& Qiu 2008). While Trichodesmium itself is apparently subject to low grazing rates (Capone et al. 1997), field experiments have shown that a large portion (up to $47 \%$ ) of the nitrogen fixed by Trichodesmium may be transferred to co-occurring 
99 primary producers thus fueling blooms of other species (e.g., Mulholland et al. 2014). Consequently, Trichodesmium blooms are considered to be likely of considerable importance in overall budgets of energy and matter in the oligotrophic gyres (Dore et al.

102 2008).

The OUTPACE cruise was designed specifically to sample a variety of trophic conditions across a large zone in the SE Pacific Ocean in which blooms of Trichodesmium 105 have been reported. Here we present data from sampling at two contrasting stations separated by $500 \mathrm{~km}$ between Fiji and Tahiti (Fig. 1), each occupied for a one-week period. To our knowledge these are first data on microzooplankton in a Trichodesmium

108 bloom and the first data on short-term temporal variability in tropical oceanic waters. We hypothesized that the tintinnid assemblage in the Trichodesmium bloom station, with relatively high concentrations of food resources, would support a larger population

111 but of reduced diversity, based on observations from the SE Pacific (Dolan et al. 2007). Data from a wide range of conditions encountered across the SE Pacific overall suggested that tintinnid diversity was negatively related to chlorophyll concentration

114 and positively related to chlorophyll dispersion as the depth of the chlorophyll maximum layer (Dolan et al. 2007). We predicted then that the 'hot spot' of productivity would show lower species richness, and lower species turnover compared to the

117 assemblage in a typical oligotrophic site.

$=>$ insert Figure 1 here at 1 column width file

120 "F1_Outpace_B_Cchlorophyll_map.jpeg"

\section{MATERIALS AND METHODS}

\section{Sampling and sample analysis}

126 Sampling was conducted through the oceanographic project 'OUTPACE'. The program was centered around observing variability in water column processes at sites across the South West Pacific by sampling stations between New Caledonia and Tahiti

129 (https://outpace.mio.univ-amu.fr/spip.php?rubrique26). Here we report data from two 'long' stations, each occupied for a 7 day period in March 2015: Station "B" $18.24^{\circ} \mathrm{S}$, $170.8^{\circ} \mathrm{E}$ and approx. $500 \mathrm{~km}$ distant, Station "C" $18.42^{\circ} \mathrm{S}, 165.94^{\circ} \mathrm{E}$. Analysis of satellite

132 images preceeding, throughout the cruise, and shortly after were compiled to allow assessment of the short-term history of the study areas (De Verneil, in prep.). Samples were obtained on days $1,3, \& 5$; On each day 6 depths were sampled between the

135 surface and the bottom of the chlorophyll maximum depth (based on data from a CTD equipped with a fluorescence probe) using $20 \mathrm{l}$ Niskin bottles. For each discrete-depth sample, a 10 l volume was concentrated to $50 \mathrm{ml}$ by slowly and gently pouring the water

138 through a $20 \mu \mathrm{m}$ mesh Nitex screen fixed to the bottom of a $10 \mathrm{~cm}$ dia. PVC tube. Concentrated water samples were fixed with Lugol's solution (2 \% final conc.), 2-3 ml aliquots were settled in sedimentation chambers and examined using an inverted

141 microscope at 200x total magnification. Thus for each date, material from $60 \mathrm{l}$ of water was examined, yielding a total of over 1,000 tintinnids for each of the stations. To assess the abundance and composition of the entire ciliate community, whole water samples

144 from same Niskin bottles sampled on days 1 \& 5 were fixed with Lugol's (2 \% final conc.); $100 \mathrm{ml}$ aliquots were settled in sedimentation chambers and examined using an inverted microscope at 200x total magnification. Phytoplankton composition was

147 assessed in a single surface water sample from each station. A $50 \mathrm{ml}$ aliquot of Lugol's- 
fixed whole water was settled and examined using an inverted microscope at 200x total magnification. Abundance and lengths of Trichodesmium filaments were determined along with abundances of dinoflagellates and diatoms. All microscopic examinations employed an Olympus inverted microscope, model IX51 equipped with DIC optics, an Olympus DP71 digital camera and Olympus Cell Sense Image Analysis software (Olympus, Rungis, France) used for cell measurements and imaging. For data reported here as average water column concentrations we employed a trapezoidal integration from the surface to the lowest depth sampled.

156 Tintinnid identifications were made based on lorica morphology and following Kofoid \& Campbell (1929; 1939), Marshall (1934) and Hada (1938). Species of certain tintinnid genera are known to display different lorica morphologies (e.g., Laval-Peuto,

159 1983; Bachy et al. 2013; Kim et al. 2013; Santoferrara et al. 2015). However, only a few of the species encountered in this study appeared variable and may or may not represent single species (e.g. Dadayiella ganymedes-acuta-bulbosa). We adopted a

162 'conservative diversity' approach, considering very similar 'species' of the same genus and near identical LOD to be a single taxon. Empty lorica were not enumerated. Morphological categories consisted of size-classes of lorica oral diameter (LOD). Each

165 species was assigned the average dimensions reported in Kofoid \& Campbell (1929, 1939) and Marshall (1969). Size-class diameters were binned over $4 \mu \mathrm{m}$ intervals beginning with the overall smallest diameter $(12 \mu \mathrm{m})$ and continuing to the largest

168 diameter encountered in a given sample.

\section{Data Analysis}

171 Taxonomic diversity was estimated for each sample as the Shannon index (ln-based, e.g., Magurran, 2004) and species richness. Morphological diversity was estimated by placing species into size-classes of lorica oral diameter (LOD). For each sample, morphological

174 diversity was estimated as the number of size-classes and a Shannon index of morphological diversity calculated using numbers and proportional importance of different size classes (ln-based).

177 Using the pooled data set from the three sampling dates, we constructed log-rank abundance curves for the tintinnid assemblages by calculating relative abundance for each species and ranking species from highest to lowest and plotting $\ln$ (relative

180 abundance) vs. rank. In parallel we also examined the abundance distributions of morphological categories by substituting the category 'species $\mathrm{x}$ ' with 'LOD size-class $\mathrm{x}$ '. For both species and LOD size-classes, we constructed hypothetical log-rank abundance

183 curves that could fit the data by using parameters of the particular assemblage. We constructed curves for three different models of community organization: geometric series, log-series, and log-normal, as in several previous studies (Raybaud et al. 2009;

186 Claessens et al. 2010; Doherty et al. 2010; Dolan et al. 2007, 2009, 2013, 2016; Dolan \& Stoeck 2011).

A geometric series distribution represents the result of the priority exploitation

189 of resources by species arriving sequentially in a community (Whittaker, 1972), and is modeled by assuming that each species' abundance is proportional to a fixed proportion $\mathrm{p}$ of remaining resources. Thus the relative abundance of the ith species is (1-p)pi-1. For 192 the tintinnid samples we used the relative abundance of the most abundant species to estimate $p$.

A log-series distribution represents the result of random dispersal from a larger community, a metacommunity in Hubbell's neutral theory (Hubbell, 2001). In a community exhibiting a log-series distribution, species having abundance n occur with 
frequency $\alpha \mathrm{xn} / \mathrm{n}$, where $\mathrm{x}$ is a fitted parameter and $\alpha$ is Fisher's alpha, a measure of species diversity that is independent of total community abundance. For a given community with $\mathrm{N}$ total individuals and $\mathrm{S}$ species, $\mathrm{x}$ can be found (Magurran, 2004) by iteratively solving the following equation for $\mathrm{x}: \mathrm{S} / \mathrm{N}=-\ln (1-\mathrm{x})(1-\mathrm{x}) / \mathrm{x}$ and then finding

201 Fisher's alpha as $\alpha=\mathrm{N}(1-\mathrm{x}) / \mathrm{x}$. For the tintinnid assemblages, we simply used the observed $\mathrm{S}$ and $\mathrm{N}$ for each sample to calculate $\mathrm{x}$ and $\alpha$.

Log-normal species abundance distributions are thought to result from either a

204 large number of species of independent population dynamics with randomly varying (in either space or time) exponential growth. Consequently, N(i) $\propto$ eri where ri is a random variable. Since N(i) is a function of an exponential variable, $\ln (\mathrm{N}(\mathrm{i})$ ) should be 207 normally distributed (May 1975). Species in a community that are limited by multiple factors that act on population size in a multiplicative fashion should also exhibit a lognormal distribution of abundances. We calculated the expected log-normal species

210 abundance distribution for each tintinnid sample by calculating the mean and standard deviation of $\ln$ (abundance) and using these parameters to generate expected abundance distributions for the $S$ species in the sample using the NORMSINV function in an Excel ${ }^{\circledR}$

213 spreadsheet. We then calculated the mean abundance for each species, ranked from highest to lowest, and then calculated relative abundance. For each of the model distributions we also examined the abundance distributions of morphological categories 216 by substituting the category 'species $\mathrm{x}$ ' with 'LOD size-class $\mathrm{x}$ '.

For the assemblages from the two stations, the observed rank abundance distributions were compared to the hypothetical models using a Bayesian approach: an

219 Akaike Goodness of fit test (Burnham \& Anderson, 2004). In this test, an Akaike Information Criterion (AIC) was determined as the natural logarithm of the mean (sum divided by $S$ ) of squared deviations between observed and predicted $\ln$ (relative

222 abundance) for all ranked $S$ species plus an additional term to correct for the number of estimated parameters, $\mathrm{k}$ ( 1 for geometric series and 2 each for log-series and log-normal distributions): $(\mathrm{S}+\mathrm{k}) /(\mathrm{S}-\mathrm{k}-2)$. The lower the calculated AIC value, the better the fit. A

225 difference of 1 in AIC corresponds roughly to a 1.5 evidence ratio. Following Burnham and Anderson (2002) we consider differences in AIC of less than 1 to represent indistinguishable fits among modeled distributions.

\section{Chlorophyll Determinations}

Seawater samples from 6 depths were collected from the Niskin bottles of the rosette

231 sampler. Volumes between 5.6 and $1 \mathrm{~L}$ (depending on the trophic conditions) were filtered onto $25 \mathrm{~mm} \mathrm{GF} / \mathrm{F}$ filters, and the filters stored in liquid nitrogen at $-80^{\circ} \mathrm{C}$ until analysis on land. The samples were extracted in 3mL methanol for a minimum of $1 \mathrm{~h}$,

234 with filter disruption by ultra-sonication. The clarified extracts were injected onto an Agilent Technologies 1100 series High Performance Liquid Chromatography (HPLC) system equipped with a refrigerated auto sampler and a column thermostat,

237 according to a modified version of the method described by Van Heukelem and Thomas (2001). Separation was achieved within 28 min during a gradient elution between a Tetrabutylammonium actetate: Methanol mixture (30:70) and 100\% methanol. The

240 chromatographic column, a Zorbax-C8 XDB $(3 \times 150 \mathrm{~mm})$ was maintained at $60^{\circ} \mathrm{C}$. Chlorophyll a, divinyl chlorophyll a and derived products were detected at $667 \mathrm{~nm}$ and the other accessory pigments at $450 \mathrm{~nm}$ using a diode array detector. (Detection limits for chlorophyll a were $0.0001 \mathrm{~g} \mathrm{~g} \mathrm{l}^{-1}$, injection precision was $0.4 \%$ ). The different 
pigments were identified using both their retention times and absorption spectra. Quantification involved an internal standard correction (Vitamin E actetate) and a

246 calibration with external standards provided by DHI Water and Environment (Denmark).

\section{Primary production}

Carbon fixation estimates followed the experimental protocol recommended by FranceJGOFS-P.F.O. (1988) and given in detail in Moutin and Raimbault (2002). Description of

252 the full experimental protocol and all of the in situ incubations conducted throughout the cruise will appear elsewhere (Gimenez, in prep.); here only data from two of the long stations (B \& C) are reported. Briefly, samples were obtained with 12-l Niskin bottles at

2559 depths chosen according to the CTD fluorescence profiles. Each sample (320-ml polycarbonate bottle, 3 light and one dark sample per depth) was collected before sunrise, inoculated with $150 \mu \mathrm{l}$ of the $14 \mathrm{C}$ working solution just before sunrise, and then

258 incubated in situ on a mooring line for 24 hours. After incubation, the samples were filtered on GF/F filters to measure net absorption (AN mg C m-3). Filters were immediately covered with $500 \mu \mathrm{l}$ of $\mathrm{HCl} 0.5 \mathrm{M}$ and stored for subsequent analysis in the

261 laboratory. Before each incubation, 3 samples were filtered immediately after inoculation and $250 \mu \mathrm{l}$ of sample was taken at random from 3 bottles and stored with $250 \mu \mathrm{l}$ of ethanolamine to determine the quantity of added tracer (Qi). In the laboratory, 264 samples were dried for $12 \mathrm{~h}$ under and extractor hood, $10 \mathrm{ml}$ of Ultimagold-MV (Packard) were added to the filters and samples then analysed using a Packard Tri carb 2100 TR liquid scintillation counter. Data reported here are average integrated primary production, a trapezoidal integration from the surface to $110 \mathrm{~m}$ depth.

\section{RESULTS}

\section{Station Phytoplankton Characteristics}

Station B was located in an area of high surface layer chlorophyll as shown in satellite

273 images (Fig. 1.). Analysis of satellite images preceding and throughout the cruise showed the bloom developed in mid-February and disappeared in late March (De Verneil, in prep.). The March 15th surface sample (from $6 \mathrm{~m}$ ) contained a dense population of

276 filaments and tufts of Trichodesmium c.f. erythraeum (Fig. 2). Filaments ranged in length from $40-1500 \mu \mathrm{m}$ with a total concentration, in linear terms, equal to about $2 \mathrm{~m}$ of Trichodesmium filament $\mathrm{l}^{-1}$. Also present were dinoflagellates, dominated by small cells

279 (20 $\mu \mathrm{m}$ dia.) found in abundances of about $2000 \mathrm{l}^{-1}$ and large diatoms $(>50 \mu \mathrm{m})$, approx. 500 cells l$^{-1}$. Chlorophyll concentrations were maximal near the surface with a second peak at about 75m depth (Fig. 3). Primary production averaged $4.0 \mu \mathrm{g} \mathrm{C} \mathrm{l}^{-1} \mathrm{~d}^{-1}$ (Table 1 ).

$=>$ insert Fig. 2 here at 1 column width file

"F2_10xTrichodesmiumOutpaceCTD110.jpeg"

Station $C$ was located in an area of very low surface layer concentrations of

288 chlorophyll (Fig. 1). The chlorophyll maximum layer was located at about $150 \mathrm{~m}$ depth (Fig. 3). The surface sample from Station C, taken on March 27 (from $6.5 \mathrm{~m}$ ), contained few Trichodesmium filaments with a total concentration, in linear terms, equal to about $0.2 \mathrm{~m}$ of Trichodesmium filaments $\mathrm{l}^{-1}$. Compared to Station $\mathrm{B}$, dinoflagellates and 
diatoms were found in lower concentrations of about $1000 \mathrm{l}^{-1}$ and $100 \mathrm{l}^{-1}$, respectively. Primary production averaged $2.0 \mu \mathrm{g} \mathrm{C}^{-1} \mathrm{l}^{-1}$, half the rate found at Station B (Table 1).

\section{Ciliate Abundances \& Vertical Distributions}

At Station B average water column concentrations of both tintinnids, and all planktonic 297 ciliates, ranged narrowly: 9.0-11.0 tintinnids $\mathrm{l}^{-1}$ and 570-710 total ciliates $\mathrm{l}^{-1}$. However vertical distributions were quite irregular either comparing days or groups (Fig. 3). At

Station $C$ average water column concentrations also ranged narrowly: 5.7- 6.2 tintinnids

$300 \mathrm{I}^{-1}$ and 670-730 total ciliates $\mathrm{l}^{-1}$. In contrast to Station $\mathrm{B}$, vertical distributions were similar between groups and with time (Fig. 3). The marked differences in the vertical distributions suggest that Station B populations were dynamic compared to the

303 apparent steady state of Station C populations. For both Station B and Station C there were no clear differences in the species composition of the tintinnid assemblages with depth in accordance with findings from previous studies (e.g., Dolan 2000; Dolan et al.

306 2009). Water column profiles of temperature, salinity and density were nearly invariant and identical at the 2 stations (data not shown) supporting the hypotheses that variability in vertical distributions found in Station B populations reflected biological

309 interactions rather than physical dynamics.

=> Insert here Figure 3 at full page width file "F3_tin\&CilProfiles.jpeg"

\section{Tintinnid Assemblages}

At Station B the assemblage was highly dominated (about 30\% of total cells) by a single

315 species, Favella sp. (Fig. 4a), not found in Station C, and it alone accounted for about half of the twofold difference in the overall abundance of tintinnids comparing the two stations (Table 1). In contrast, the most abundant species at the oligotrophic Station C,

318 Steenstrupiella steenstrupii (Fig. 4 b) accounted for only $12 \%$ of the population. At both stations the species richness was high, ranging from day to day from 46 to 54 at Station B and 43 to 56 at Station C. Numbers of 'trace species', found as one cell in the $60 \mathrm{l}$ 321 examined for each day, were also of similar magnitude at the two sites ranging from 7 to 16 and 7 to 17, respectively, at Stations B and C. Total species richness at the two sites was numerically identical at 71 species. Metrics of morphological diversity, H' values of

324 LOD size-classes, and the numbers of size-classes found, were only slightly lower in the Station B assemblage (Table 1). Analysis of abundance distribution patterns (Table 2 \& Fig. 5) indicated similar population structure in Stations B and C. Species abundance

327 distributions were lognormal or log-series (i.e., not significantly different fits) and the size-class abundance distributions were both best modeled by a geometric distribution. However, there were some differences in the two assemblages other than the presence of a relatively dense population of Favella sp. at Station B.

=> insert here Figure 4 at 1 column width file "F4_FavSteen.jpeg" and Figure 5 at 1 column width "F5_abundanceDistrib.Jpeg"

=> Insert Here Table 1 and Table 2 .

There were differences in the size-structure of the two assemblages. In the Station $C$ assemblage, the number of species in an LOD size-class was positively related to the number of cell in the size class. In the Station B assemblage, there was no significant relationship between the number of species in a given size-class of LOD and 
the number of cells in that size class. This was the case both with and without including the Favella sp. data (Fig. 6). The species inventory also differed in composition between the two sites. There were 13 species found in Station B absent from Station C, and 23 species found in Station C absent from Station B. There were interesting similarities in

345 the characteristics of the species found in one site only. The 'one site only' species were mostly those with an LOD size close to that of the Station B dominant Favella sp. (Fig. 7). Most of the species found with Favella at Station B, but not at Station C, had an LOD close 348 to that of the Favella sp. Similarly, the species found in Station C, but absent from the Favella-dominated assemblage, have an LOD close to that Favella. Thus most of the difference in the species inventories of the high producitivity and oligotrophic sites

351 concerned forms with of an LOD close to the Favella sp. of the high productivity site. The tintinnid data by date is provided in a Supplemental File.

354 => Insert Figure 6 at 1 column width file "F6_sppLOD_SC.jpeg" and Figure 7 at 1 column width file "F7_AbsentSpp.jpeg"

\section{DISCUSSION}

360 We expected to find distinct differences between the population structure of a tintinnid assemblages in a 'hot spot' of productivity site compared to a typical oligotrophic site. Specifically, we expected the high productivity site to harbor a larger population but of

363 lower species richness and show lower variability in the total species inventory from day to day. These expectations were based on the patterns found in the SE Pacific where across a large gradient of stations tintinnid diversity was negatively related to average

366 chlorophyll concentration and positively related to the depth of the chlorophyll maximum layer (Dolan et al. 2007). It is unclear exactly what mechanism is behind the relationship. The two parameters, depth of the maximum concentration of chlorophyll

369 and average water column concentration, are themselves usually strongly and inversely related. The depth of the surface mixed layer often, but not always, corresponds with the depth of the chlorophyll maximum layer (Cullen 1982). The large-scale pattern of

372 diversity in planktonic foraminfera has been related to the depth of the surface mixed layer. In planktonic forminifera assemblages diversity increases with the depth of the surface mixed layer; high diversity corresponding with a mixed layer of a larger volume

375 (Rutherford et al. 1999). Regardless of the mechanism behind the large-scale geographic pattern relating depth of the chlorophyll maximum layer and diversity, our data show that a site with a shallow chlorophyll maximum (St B) can harbor high species diversity.

378 Our comparison of communities from sites differing in primary productivity, chlorophyll concentration, and chlorophyll vertical distribution revealed some differences. The variability in the vertical profiles of both total ciliates and tintinnids

381 (Fig. 3) suggested that the microzooplankton overall was highly dynamic in St. B compared to St. C. The 'hot spot' of productivity had a tintinnid community highly dominated by one species. The two populations differed in abundance by about a factor

384 of 2 , roughly corresponding to the differences in rates of primary productivity (pooled data, Table 1). There were also differences in the temporal variability of vertical distributions (Fig. 3), species inventories, and the strength of size-structuring in the 387 assemblages i.e., the relation ship of species richness of an LOD size-class and the number of cells in the size-class (Fig. 6). Overall however the populations were largely similar in terms of species richness, patterns of abundance distributions (Fig. 4) and 
390 showed the same turn over or temporal variability in species inventories. Furthermore the metrics of morphological diversity were quite similar as well (Table 1). The overall characteristics of both assemblages were very much like those found in the oligotrophic sites in the SE Tropical Pacific (Dolan et al. 2007). Specifically the sites in the SE Tropical Pacific with deep ( $>150 \mathrm{~m}$ ) chlorophyll maximum layers and low chlorophyll concentrations were found to harbor assemblages of 21-41 spp with Shannon Index values of $2.6-3.2$, values quite similar to those reported here (Table 1). Furthermore, there were no obvious differences in the communities of non-tintinnid ciliates; at both stations the numerically dominant form was a small (15 $\mu \mathrm{m}$ dia.) oligotrichid form. Our 399 results suggest that tropical microzooplankton populations do not change dramatically in a transient period of high primary productivity.

The effects of transient phytoplankton blooms on other components of the planktonic food web have been investigated as part of large-scale iron fertilization experiments. However data are quite sparse with regard to effects on microzooplankton. The experiments mostly have been conducted in high latitude sites in both the southern

405 and northern hemispheres. These studies have yielded contradictory results with regard to effects on other components of the plankton. In the EIFEX experiment in the Antarctic circumpolar current, the experimentally induced bloom yielded large shifts in the

408 protozooplankton assemblage, including tintinnid assemblages (Assmy et al. 2014). However, during the EisenEx experiment in the Southern Ocean no major changes occurred in the composition of the bacterial community based on phylogenetic

411 signatures (Arrieta et al. 2004). Similarly, in the LOHAFEX iron fertilization experiment in the South Atlantic, while chlorophyll concentrations increased by a factor of 3 , the prokaryote populations were "remarkably constant" (Thiele et al. 2012) as was the 414 composition of eukaryotic nanoplankton (Thiele et al. 2014). In the Subarctic Pacific, iron enrichment in the SERIES study, in NE Subarctic Pacific, resulted in little change in the community composition of the mesozooplankton (Sastri \& Dower 2006). In the

417 SEEDS experiment, in the western Subarctic Pacific, the only notable shift in the microzooplankton was an increase in the abundance of heterotrophic dinoflagellates (Saito et al. 2005).

Our findings of overall similarity in assemblages of tropical tintinnids in a productivity 'hot spot', compared to a non-hot spot, may reflect the fact that the productivity of the 'hot spot' we sampled was not sufficiently elevated compared to the reference site to provoke a marked change in the tintinnid assemblage other than the development of a single species. Alternatively perhaps as the bloom was relatively old when we were sampling, having begun about a month earlier, the tintinnid assemblage was in transition towards typical oligotrophic site assemblage. Cleary it would be desirable to sample more stations and survey populations throughout the occurrence of a phytoplankton bloom. Unfortunately, oceanographic expeditions are complex, costly and infrequent limiting severely our access to natural populations in remote sites of oligotrophic tropical systems. We can only hope that future expeditions will provide additional opportunities to investigate these fascinatingly diverse assemblages.

\section{CONCLUSIONS}

435 We examined the characteristics of tintinnid ciliate assemblages in the South West Pacific Ocean. We analyzed 2 assemblages, comparing one found in a site with high primary productivity associated with a bloom of the nitrogen-fixing cyanobacterium Trichodesmium with the assemblage found in a typical oligotrophic site. Tintinnid 
abundance differed between the sites by a factor of 2 and a species absent from the oligotrophic site, highly dominated the 'hot spot' site. Despite some differences in the

441 species inventories of the two assemblages, total species richness was identical. Both morphological diversity and temporal variability were similar as well. For both assemblages, the species abundance distributions were most closely fit by a log-series or

444 log-normal distribution, and the abundance distributions of ecological types, forms of distinct lorica oral diameter, were the typical geometric as found in assemblages from other tropical and subtropical sites. Despite large differences in population size and

447 dominance, the two populations were similar by most measures. We found that populations of these plankton grazers in 'hot spots' of phytoplankton productivity in oligotrophic systems may not differ from those in surrounding oligotrophic areas.

\section{ACKNOWLEDGEMENTS}

453 This is a contribution of the OUTPACE project (Oligotrophy to UlTra-oligotrophy PACific Experiment) funded by the French national research national agency (ANR) through the project ANR-14-CE01-0007-01 with additional funding provided by the LEFE-CyBER program (CNRS-INSU), the GOPS program (IRD) and the CNES. The OUTPACE project was managed by T. Moutin and S. Bonnet from the MIO (OSU Institut Pytheas, AMU, Marseilles, France). The authors thank the crew of the RV L'Atalante for outstanding shipboard operation. G. Rougier and M. Picheral are warmly thanked for their efficient help in CTD rosette management and data processing. David Montagnes provided comments on an earlier draft of this paper. The reviewers provided helpful advice on an earlier version of the paper. We retain full credit for all errors of fact, interpretation and omission. 


\section{LITERATURE CITED}

471

474

477

480

483

486

489

492

495

498

501

510

513

504 Claessens, M., Wickham, S.A., Post, A.F. \& Reuter, M. 2010. A paradox of the ciliates? High

507 Cleve, P.T. 1899. Some Atlantic Tintinnodea. Ofversigt af Kongl. Vetenskaps-Akademiens

Agatha S., Laval-Peuto M. \& Simon, P. 2013. The tintinnid lorica. In J.R. Dolan, D. J.S. Montagnes, S. Agatha \& D.K. Stoecker (eds): The Biology and Ecology of Tintinnid Ciliates: Models for Marine Plankton. pp 17-41. Oxford: Wiley-Blackwell.

Andersen, V., Goutx, M., Prieur, L. \& Dolan, J.R. 2009. Short-scale temporal variability of physical, biological and biogeochemical processes in the NW Mediterranean Sea: an introduction. Biogeosciences, 6:453-461.

Arrieta, J.M., Weinbauer, M.G., Lute, C. \& Herndll, G.J. 2004. Response of bacterioplankton to iron fertilization in the Southern Ocean. Limnol. Oceanogr., 49:799-808.

Assmy, P., Cisewski, B., Henjes, J., Klaas, C., Montresor, M. \& Smetacek, V. 2014. Response of the protozooplankton assemblage during the European Iron Fertilization Experiment (EIFEX) in the Antarctic circumpolar current. J. Plank. Res., 36: 1175-1189.

Bachy, C., Dolan, J.R., López-García, P., Deschamps, P., \& Moreira, D. 2013. Accuracy of protist diversity assessments: morphology compared to cloning and direct pyrosequencing of 18S rRNA genes and ITS regions using the conspicuous tintinnid ciliates as a case study. ISME J., 7: 244-255.

Beers, J.R. 1982. An introduction and historical overview. Ann. Inst. Océanogr. Paris, 58 : 5-14.

Burnham K.P. \& Anderson, D.R. 2002. Model selection and multi-model inference: a practical information-theoretic approach. Springer, New York, NY.

Calbet, A. \& Landry, M.R. 2004. Phytoplankton growth, microzooplankton grazing, and carbon cycling in marine systems. Limnol. Oceanogr., 49: 51-57.

Capone, D.C., Zehr, J.P., Paerl, H.W., Bergman, B. \& Carpenter, E.J. 1997. Trichodesmium, a globally significant marine cyanobacterium. Science, 267: 1221-1229. ciliate diversity in a resource-poor environment. Mar. Biol. 157:483-494. Förhandlingar 56: 969-975.

10 Cullen, J.J. 1982. The deep chlorophyll maximum: comparing vertical profiles of chlorophyll a. Can. J. Fisher. Aquat. Sci., 39:791-803.

Doherty, M., Tamura, M., Costas, B.A., Ritchie, M.E., McManus, G.B. \& Katz, L. A. 2010. Ciliate diversity and distribution across an environmental and depth gradient in Long Island Sound, USA. Environ. Microbiol. 12:886-898. 
Dolan J. R. 2000. Tinitinnid ciliate diversity in the Mediterranean Sea: Longitudinal patterns related to water column structure in late spring-early summer. Aquat. Microb. Ecol. 22: 69-78

Dolan, J.R. 2010. Morphology and ecology in tintinnid ciliates of the marine plankton: correlates of lorica dimensions. Acta Protozool. 49, 235-344.

Dolan, J.R. 2013. Introduction to tintinnids. In Dolan, J.R., Montagnes, DJ.S., Agatha, S. \& 525 Stoecker, D.K. (eds) The Biology and Ecology of Tintinnid Ciliates: Models for Marine Plankton. Wiley-Blackwell: Oxford, pp 1-16.

528 Dolan, J.R \& Stoeck, T. 2011. Repeated sampling reveals differential variability in measures of species richness and community composition in planktonic protists. Environ Microbiol. Rep. 3:661-666.

Dolan, J.R., Jacquet, S. \& Torreton, J.-P. 2006. Comparing taxonomic and morphological biodiversity of tintinnids (planktonic ciliates) of New Caledonia. Limnol. Oceanogr. 51: $534 \quad 950-958$.

Dolan, J.R., Ritchie, M.R. \& Ras, J. 2007. The neutral community structure of planktonic 537 herbivores, tintinnid ciliates of the microzooplankton, across the SE Pacific Ocean. Biogeosciences 4: 397-410.

540 Dolan, J.R., Ritchie, M.E., Tunin-Ley, A. \& Pizay, M.-D. 2009. Dynamics of core and occasional species in the marine plankton: tintinnid ciliates in the north-west Mediterranean Sea. J. Biogeogr. 36, 887-895.

Dolan, J.R., Landry, M.R. \& Ritchie, M.E. 2013. The species-rich assemblages of tintinnids (marine planktonic protists) are structured by mouth size. ISME J., 7: 1237-1243.

Dolan, J.R., Yang, E.J., Kang, S.-H. \& Rhee, T.S. 2016. Declines in both redundant and trace species characterise the latitudinal diversity gradient in tintinnid ciliates. ISME J., 10: in

549 press (doi:10.1038/ismej.2016.19)

Dore, J.E., Letelier, R.M., Church, M.J., Likas, R. \& Karl, D.M. 2008. Summer phytoplankton 552 blooms in the oligotrophic North Pacific Gyre: Historical perspective and recent observations. Prog. Oceanogr., 76: 2-38.

555 Hada, Y. 1938. Studies on the Tintinnoinea from the Western Tropical Pacific. J. Fac. Sci. Hokkaido Imperial Univ., Series 6, Zoology, 6: 87-190.

558 Hubbell, S.R. 2001 The unified neutral theory of biodiversity and biogeography. Princeton, Princeton University Press, Princeton, NJ.

561 Laval-Peuto, M. 1983. Sexual reproduction in Favella ehrenbergii (Ciliophora, Tintinnina). Taxonomical implications. Protistologica, 19, 503-512. 
564 Laval-Peuto, M. \& Brownlee, D.C. 1986. Identification and systematics of the Tintinnina (Ciliophora): evaluation and suggestion for improvement. Ann. Institut Océanogr. Paris 62: 69-84.

Kim, S.Y., Choi, J.K., Dolan, J.R., Shin, H.C., Lee, S. \& Yang, E.J. 2013. Morphological and ribosomal DNA-based characterization of six Antarctic ciliate 5 morphopecies from the Amundsen Sea with phylogenetic analyses. J. Eukary. Microbiol., 60: 497-513.

Kofoid, C.A. 1930. Factors in the evolution of the Tintinnoinea. in Contributions to Marine Biology. Stanford University Press, Palo Alto, CA. pp 1- 39.

Kofoid CA, Campbell AS. 1929. A conspectus of the marine and freshwater ciliata belonging to the suborder Tintinnoinea, with despcriptions of new species principally from the Agassiz Expedition to the Eastern Tropical Pacific 1904-1905. Univ. Calif. Publ. Zool., 34: 1-403.

Kofoid, C.A., and Campbell, A.S. 1939. Reports on the scientific results of the expedition to the Eastern Tropical Pacific, in charge to Alexander Agassiz, by U.S. Fish Commission Steamer "Albatross" from October 1904 to March 1905, Lieut. Commander L.M. Garrett, U.S.N. commanding. 37. The Ciliata: the tintinnoinea. Bull. Mus. Compar. Zool, Harvard, 84, 1-473.

JGOFS. 1988. Core measurements protocols : report of the core measurement working group. JGOFS report $n^{\circ} 6$, Joint Global Ocean Flux Study, SCOR 1-40.

Magurran, A.E. 2004. Measuring biological diversity, 2nd Ed. Blackwell, Oxford, U.K.

591 Marshall, S.M. 1934. The silicoflagellata and Tintinnoinea. Great Barrier Reef Expedition 1928-1929. Sci. Rep., 6: 623-664.

594 Marshall, S.M. 1969. Protozoa, order Tintinnia. Conseil International pour l'Exploration de la Mer, Fiches d'Identification de Zooplancton, fiches 117-127.

597 May, R.M. 1975. Patterns of species abundance and diversity. In: Cody, M.L. \& Diamond, J.M. (eds) Ecology and evolution of communities, Harvard University Press, Boston MA., pp. 81-120.

600

Montagnes, D.J.S. 2013. Ecophysiology and behavior of tintinnids. In: Dolan, J.R., Montagnes, DJ.S., Agatha, S., Stoecker, D.K. (eds) The Biology and Ecology of Tintinnid

603 Ciliates: Models for Marine Plankton. Wiley-Blackwell, Oxford, U.K. pp 85-121.

Moutin, T., \& P. Raimbault. 2002. Primary production, carbon export and nutrients 606 availability in western and eastern Mediterranean Sea in early summer 1996. MATER Special Issue. J. Mar. Syst., 33-34: 273-288.

609 Mulholland, M.R., Bernhardt, P.W., Ozmon, I., Procise, L.A., Garrett, M., O’Neil, J.M., Heil, C.A., \& Bronk, D.A. 2014. Contribution of diazotrophy to nitrogen inputs supporting Karenia brevis blooms in the Gulf of Mexico. Harmful Algae, 38:20-29 
Raybaud, V., Tunin-Ley, A., Ritchie, M. E., \& Dolan, J.R. 2009. Similar patterns of community organization characterize distinct groups of different trophic levels in the plankton of the NW Mediterranean Sea. Biogeosciences, 6:431-438.

Rutherford, S., D'Hondt, S. \& Prell, W. 1999. Environmental controls on the geographic distribution of zooplankton diversity. Nature, 400: 749-752.

Saito, H., Suzuki, K., Hinuma, A., Ota, T., Fukami, K., Kiyosawa, H., Saino, T. \& Tusuda, A. 621 2005. Responses of microzooplankton to in situ iron fertilizationin the western subarctic Pacific (SEEDS). Progr. Oceanogr. 64: 223-236.

624 Santoferrara, L.F. \& Alder, V.A. 2012. Abundance and diversity of tintinnids (planktonic ciliates) under contrasting levels of productivity in the Argentine Shelf and Drake Passage. J. Sea Res, 71: 25-30.

Santoferrara, L.F., Tian, M., Alder, V.A. \& McManus, G.B. 2015. Discrimination of closely related species in tintinnid Ciliates: new insights on crypticity and polymorphism in the genus Helicostomella. Protist, 166:78-92.

Santoferrara, L. F., Bachy, C., Alder, V. A., Gong, J., Kim, Y.-O., Saccà, A., da Silva Neto, I. D., 633 Strüder-Kypke, M. C., Warren, A., Xu, D., Yi, Z. \& Agatha, S. 2016. Updating biodiversity studies in loricate protists: the case of the tintinnids (Alveolata, Ciliophora, Spirotrichea). J. Eukaryot. Microbiol., doi:10.1111/jeu.12303

Sastri, A.R. \& Dower, J.F. 2006. Mesozooplankton community response during the SERIES iron enrichment experiment in the subarctic NE Pacific. Deep-Sea Res. II, 53:

\section{$6392268-2280$.}

Sitran, R., Bergamasco, A., Decembrini,E. \& Guglielmo, L. 2007. Temporal succession of tintinnids in the northern Ionian Sea, Central Mediterranean. J. Plank. Res., 29: 495-508.

Thiele, S., Fuchs, B.M., Ramalah, N., \& Amann, R. 2012. Microbial community response 645 during the iron fertilization experiment LOHAFEX. Appl. Environ. Microbiol., 78:88038812.

648 Thiele, S., Wolf, C., Schulz, I.K., Assmy, P., Metfies, K. \& Fuchs, B.M. 2014. Stable Composition of the Nano- and Picoplankton Community during the Ocean Iron Fertilization Experiment LOHAFEX. PLoS ONE 9: e113244.

651 doi:10.1371/journal.pone.0113244

Van Heukelem, L., \& Thomas, C. S. 2001. Computer-assisted high performance

654 liquid chromatography method development with applications to the isolation and analysis of phytoplankton pigments. J. Chromatogr. 910: 31-49.

657 Westberry, T.K. \& Siegel, D.A. 2006. Spatial and temporal distribution of Trichodesmium blooms in the world's oceans. Global Biogeochem. Cycles, 20: GB4016, doi:10.1029/2005GB002673 
Whittaker, R.H.1972. Evolution and measurement of species diversity, Taxon, 21, 213251.

663

Wilson, C., \& Qiu, X. 2008. Global distribution of summer chlorophyll blooms in the oligotrophic gyres. Prog. Oceanogr., 78: 107-134.

\section{FIGURE LEGENDS}

Figure 1. Surface chlorophyll-a concentration during the OUTPACE cruise. The ocean color satellite products were produced by Collecte Localisation Satellites

672 (http://www.cls.fr/en/).

Figure 2. A tuft of the N-fixing Trichodesmium c.f. erythraeum which was abundant in 675 Station B.

678 ciliate populations at Stations B and C plotted by date (2015); chlorophyll data were available for a single date for each site and did not include a near surface sample. Satellite data (Fig. 1) showed a surface concentration of over $1 \mu \mathrm{g}$ chlorophyll $\mathrm{l}^{-1}$ for

681 Station B (over 5 times the maximum concentration at Station C ) and a surface concentration of $0.03 \mu \mathrm{g}$ chlorophyll $\mathrm{l}^{-1}$ for Station C. Note the relatively irregular distributions found at the high primary productivity Station B compared to the nearly invariant and coherent distributions and abundances found in the Station C.

Figure 4. The left panel, A, shows the Station B dominant tintinnid form, Favella sp.; it represented over $30 \%$ of the abundant tintinnid population found in the 'hot spot' station. The form closely resembles the species depicted as Favella azorica by Marshall (1934) in both shape and dimensions, with an LOD of about $45 \mu \mathrm{m}$. However, Cleve's

690 original description as Undella azorica, gave an LOD of $66 \mu \mathrm{m}$ (Cleve 1899). Hence we term the form found in Station B Favella sp.. The right panel, B, shows the Station C dominant species Steenstrupiella steenstrupii; it represented about $12 \%$ of the Station C tintinnids.

Figure 5. Plots of the rank abundance distributions of the tintinnid assemblages from

696 Station B (St B) and Station C (St C). Right panel shows the species rank abundance distribution. Note that with the exception of the first ranked species and size class for for St B, the distributions for St B and St C are nearly identical.

Figure 6. Size structure of the tintinnid assemblages found in Stations B and C. The tintinnid assemblages were binned in categories of lorica oral diameter. Shown are only

702 lorica size categories which contained at least 10 cells. The upper panel, data from Station B, shows a near invariant number of species per size-class. In contrast, in the Station $\mathrm{C}$ assemblage, the number of cells within a size-class appears positively related 705 to the number species in the size class. Simple linear correlation analysis confirmed these patterns. For Station $C$ data there was a significant linear relationship between the number of cells and species in a size class: $r=0.70^{* *} n=14$. For Station B data there was no significant relationship between the number of cells in a size classs and the 
number of species in the size class: $\mathrm{r}=0.50 \mathrm{~ns}, \mathrm{n}=13$; excluding the dominant Favella sp did not improve the relationship: $r=0.44 \mathrm{~ns}, \mathrm{n}=13$.

711

Figure 7. Morphological characteristics (lorica oral diameter) of tintinnid species found in only one of the two sites sampled. Note that most of the 'one station only' species were of LOD sizes close to that of the Station B dominant, Favella sp..

SUPPORTING INFORMATION

Tintinnid Supplementary Data, Video of time-course changes in surface concentrations of chlorophyll a based on satellite image data.

Table 1. Summary data for tintinnid populations sampled and primary production. Data from discrete depth samples were pooled to yield total number of individuals encountered ( $\Sigma$ cells), number of species (\# spp), number of species found as a single individual (\# trace spp), Shannon diversity index for species (spp H'), numbers of LOD size-classes (\# LODs), and Shannon diversity index of LOD size-classes present (LOD H'). Primary production (PP) in $\mu \mathrm{g} \mathrm{Cl}^{-1} \mathrm{~d}^{-1}$ average integrated for the $0-110 \mathrm{~m}$ segment of the water column.

\begin{tabular}{lllllllll}
\hline population & $\begin{array}{l}\text { date } \\
\text { sampled }\end{array}$ & $\begin{array}{l}\boldsymbol{\Sigma} \\
\text { cells }\end{array}$ & $\begin{array}{l}\# \\
\text { spp }\end{array}$ & $\begin{array}{l}\text { \# trace } \\
\text { spp }\end{array}$ & $\begin{array}{l}\text { spp } \\
\text { H' }^{\prime}\end{array}$ & $\begin{array}{l}\text { \# } \\
\text { LODs }\end{array}$ & $\begin{array}{l}\text { LOD } \\
\text { H' }^{\prime}\end{array}$ & PP \\
\hline $\begin{array}{l}\text { Stat B CTD } \\
\mathbf{1 1 0}\end{array}$ & Mar 15 2015 & 572 & 46 & 7 & 3.01 & 14 & 2.16 & 3.9 \\
$\begin{array}{l}\text { Stat B CTD } \\
\mathbf{1 2 8}\end{array}$ & Mar 17 2015 & 578 & 54 & 12 & 3.25 & 16 & 2.3 & 4.6 \\
$\begin{array}{l}\text { Stat B CTD } \\
\mathbf{1 4 6}\end{array}$ & Mar 19 2015 & 771 & 52 & 16 & 2.41 & 15 & 1.84 & 3.3
\end{tabular}

$\begin{array}{lllllllll}\text { Stat C CTD } & \text { Mar 23 2015 } & 374 & 43 & 7 & 3.22 & 14 & 2.24 & 1.4 \\ 159 & \text { Mar 25 2015 } & 356 & 56 & 17 & 3.47 & 16 & 2.32 & 1.4 \\ \begin{array}{l}\text { Stat C CTD } \\ 176\end{array} & \text { Mar 27 2015 } & 337 & 49 & 17 & 3.33 & 16 & 2.24 & 1.4 \\ \begin{array}{l}\text { Stat C CTD } \\ 194\end{array} & & & & & & & \end{array}$

$\begin{array}{lllllllll}\text { Stat B Pooled } & \text { Mar 15-19 } & 1921 & 71 & 9 & 2.98 & 17 & 2.14 & \begin{array}{l}\text { avg. } \\ 4.0\end{array} \\ \text { Stat C Pooled } & \text { Mar 23-27 } & 1051 & 71 & 11 & 3.51 & 17 & 2.29 & \text { avg } 1.4\end{array}$


738 Table 2. Results of modeling abundance distribution patterns. Lowest AIC values (red) indicate the best model fit. Multiple values in red indicate indistinguishable fits (differences $<1$ ).

741 Species Abundance Distribution fits

\begin{tabular}{llll}
\hline population & Log-Normal & Geometric & Log-Series \\
\hline Stat B & 1.4 & 3.5 & 0.1 \\
Stat C & 1.2 & 2.6 & 1.0 \\
\hline
\end{tabular}

744

Size-Class Abundance Distribution fits

747

\begin{tabular}{llll}
\hline population & Log-Normal & Geometric & Log-Series \\
\hline Stat B & 2.4 & 0.3 & 2.2 \\
Stat C & 1.7 & -0.1 & 1.3 \\
\hline
\end{tabular}

750

753 


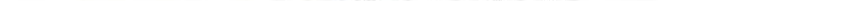


Station B

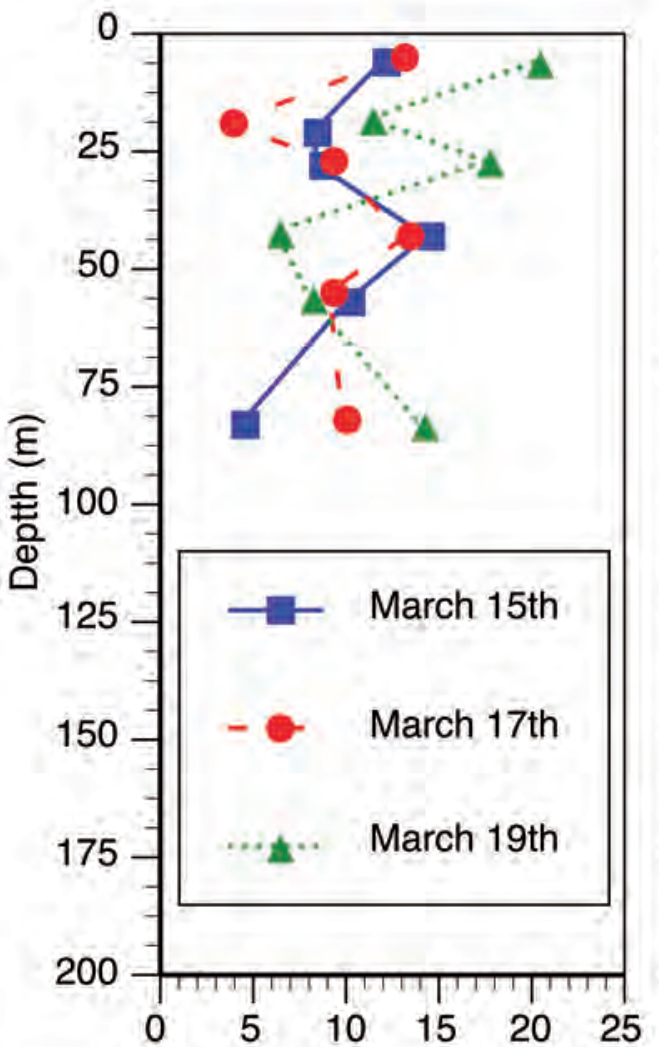

Tintinnid conc (cells $\left.\right|^{-1}$ )

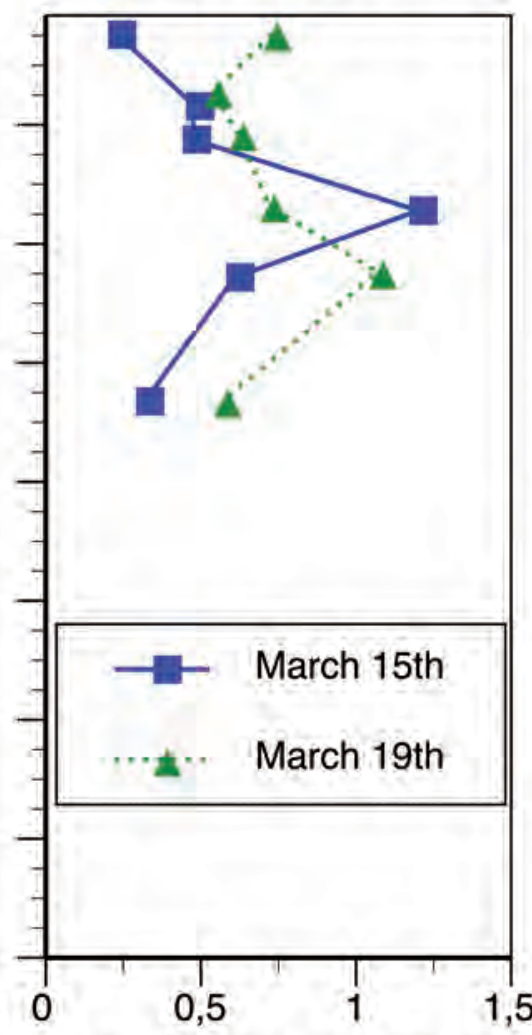

Total Ciliate Conc (cells $\mathrm{ml}^{-1}$ )

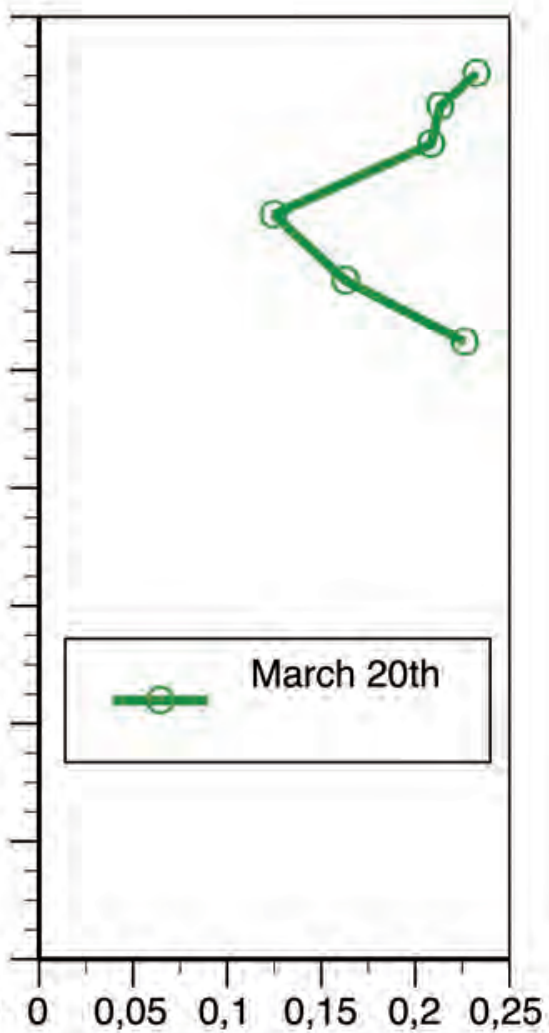

Chlorophyll a Conc $\left(\mu \mathrm{g} \mathrm{l}^{-1}\right)$

\section{Station C}
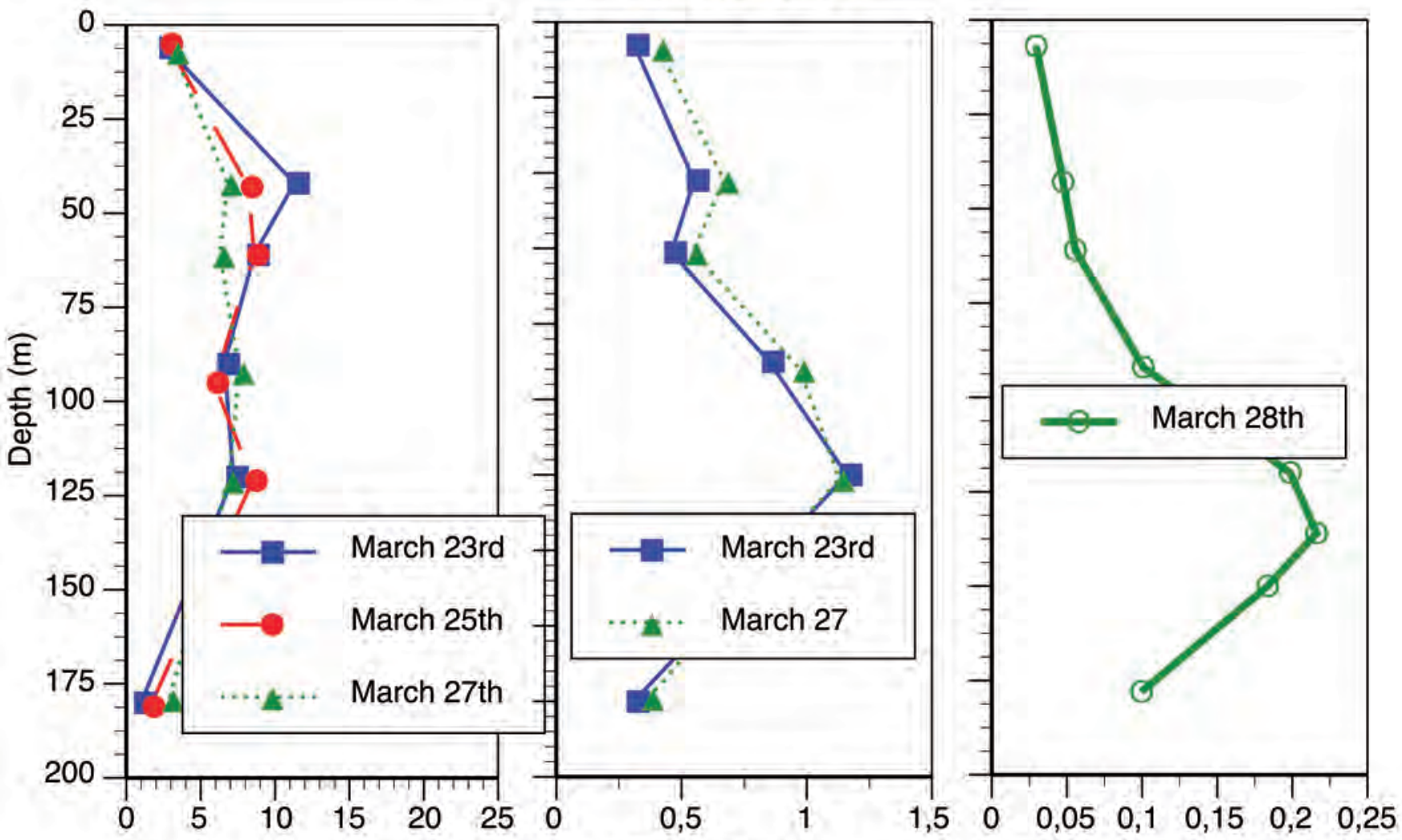

Tintinnid Conc (cells mll) $\quad$ Total Ciliate Conc (cells ml-1)

Chlorophyll a Conc $\left(\mu \mathrm{g} \mathrm{l}^{-1}\right)$ 

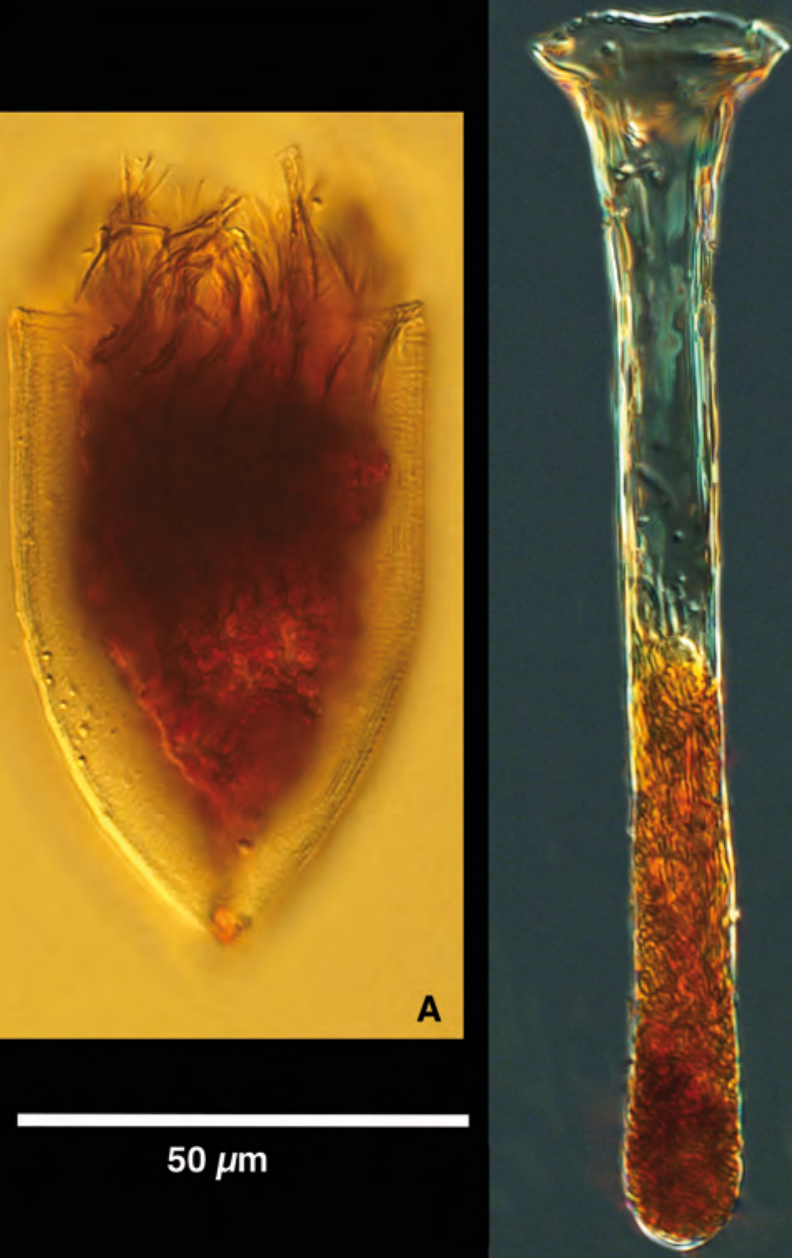

B

$50 \mu \mathrm{m}$ 

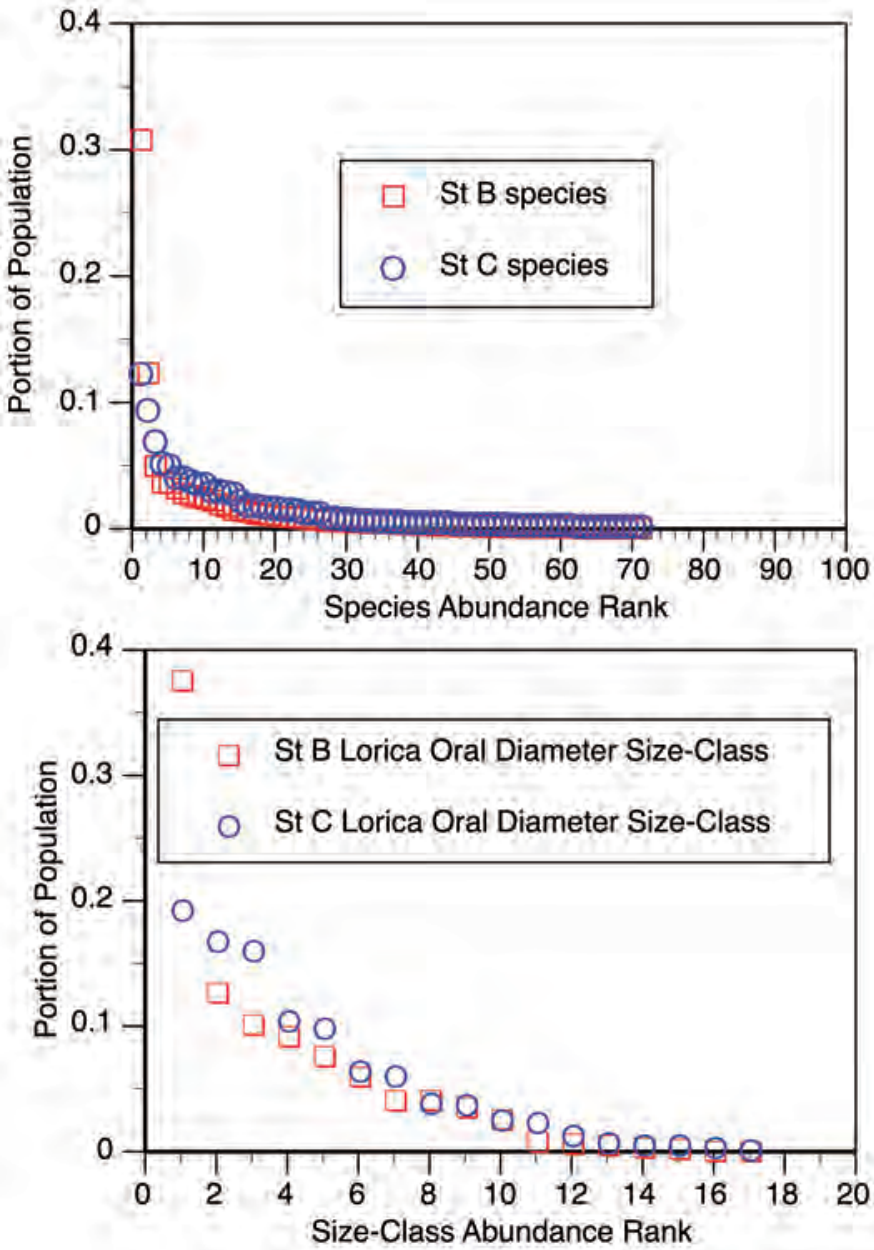


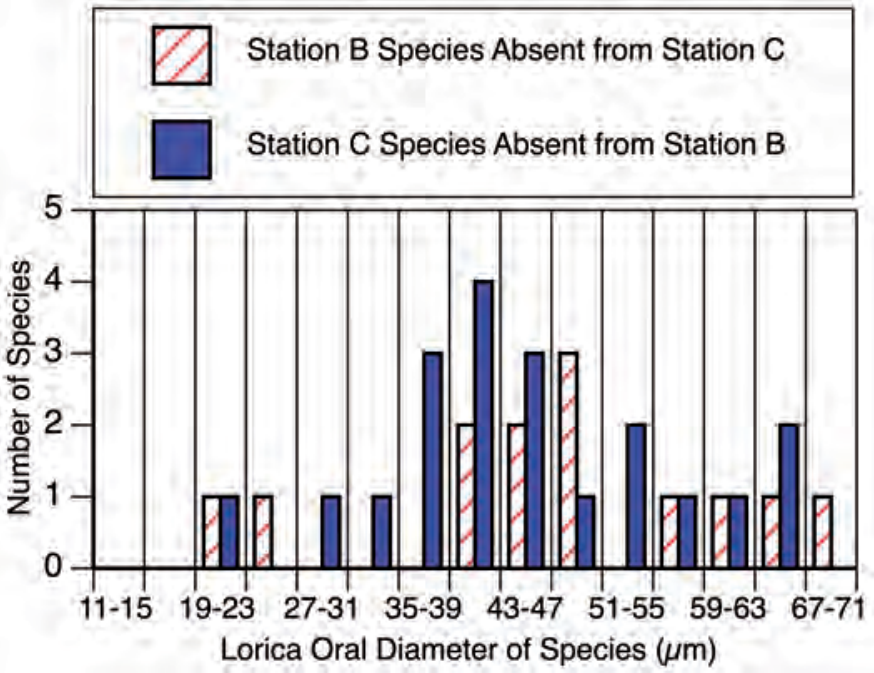

